\title{
DEVELOPMENT OF THE RURAL LANDSCAPE: THE DAČICE REGION CASE STUDY, CZECHIA
}

\author{
Jiří SCHNEIDER ${ }^{1}$, Aleš RUDA ${ }^{1}$, Michaela VENZL ${ }^{2}$
}

DOI: 10.21163/GT_2019.142.08

\begin{abstract}
:
The traditional agricultural landscape of the Czech Republic, with the advent of the Industrial Revolution, began to change slowly into an urban and industrial landscape. However, the biggest changes in the landscape character occurred in the period of world wars, in the post-war period and finally in the transformation of the economy after 1990. The importance of agricultural production in the Czech Republic is decreasing. However, in some rural areas, its position is still a tradition. The aim of the paper is to evaluate changes in the development of land use in the cadastral areas of the Dačice region in 1845, 1948, 2001 and 2014. Land use records were provided by the Czech Office for Surveying, Mapping and Cadastre and Cadastral Office in Dačice. Previous land use categories were regrouped into seven specific categories according to classification in 2014 - arable land, gardens, permanent grassland, forests, water bodies, built-up areas, and other areas and for each category, the proportional changes were computed, explained and visualized. During the monitored period, a loss of arable land in the area was found, which is gradually grassed. The area of coniferous forests is further expanding during. From the urban point of view, there is no intensive development but some evidence of new built-up areas mainly located on the open area was identified. Based on our findings we can state that results practically copy the national development of cultivated land.
\end{abstract}

Key-words: Landscape management, CORINE, Land use, Land cover, Rural region.

\section{INTRODUCTION}

Land use represents a specific demonstration of human activity in time and space (Olah et al., 2006) and it is clear that the landscape is a faithful reflection of the state and the development of a society (Lipský, 2011). The changes taking place just in the society can be distinguished according to their technological, demographic, economic, political or social character. They also reflect the way of using an arrangement of the landscape, both cultural and natural. The reasons for variable landscape researches are primarily given by serious problems in the environment, e.g. land's degradation and erosion (Bürgi, Hersperger \& Schneeberger, 2004). Different driving forces (economic factors, social factors, and general public) cause changes in the landscape and influence processes in an evolutional trajectory of the landscape itself (Bürgi, Hersperger \& Schneeberger, 2004; Bičík et al., 2001). These factors create a coherent system in relation to their mutual interaction and feedback on various levels of time and space. In the last century, land use has been especially influenced by continuing differences between cores and peripheries.

\footnotetext{
${ }^{1}$ Department of Environmentalistics and Natural Resources, Faculty of Regional Development and International Studies, Mendel University in Brno, tř. Generála Píky 2005/7, 613 00, Brno, Czech Republic; jiri.schneider@mendelu.cz; ales.ruda@mendelu.cz

${ }^{2}$ Department of Landscape Management, Faculty of Forestry and Wood Technology, Mendel University in Brno, Zemédělská 3, 613 00,Brno, Czech Republic; venzlu.m@seznam.cz
} 
The spatial structure of land use develops not only towards more and more spatial differentiation but also towards different dynamics of structural changes in territories, which are given by society in a certain stage of its development. The land use in Czechia has been clearly changing in the last two centuries, both vertically and horizontally. Hereby the regional heterogeneity of single territories hereby evolves towards more significant territorial differentiation and also different dynamics of land use functions.

Any kind of change in the context of land use and land cover has a significant role in the climatic system (Loveland \& Mahmood, 2014; Melillo et al., 2014). Except for heat production from industrial and other activities, the consequences of changes in land use (e.g. tree harvesting, rising food consumption, etc.) have had also an important influence on climatic changes (Nistor et al., 2018). Monitoring and analysis of historical changes in land use with the aim of capturing significant changes in manners in the landscape to various aspects of the environment, as well as monitoring the current state of the landscape and the development of landscape structures is currently a frequent topic. Since 1990, the number of papers on land use changes has increased significantly both at European and world level (Lipský, 2011). Among scholars, there are many approaches to landscape development assessment, e.g. Skaloš et al., 2011; Irwin \& Geoghegan, 2001; Bürgi \& Russell, 2001. Most of the papers concerning changes in the development or land use in Czechia are based on analysis of historical maps of the Stable Cadastre, e.g. Eremiášová \& Skokanová, 2009; Brůna \& Křováková, 2005a; Brůna \& Křováková 2005b; Lipský, 1994; Bičík, 2012; Št'astná et al., 2015. Plánka (2013) dealt with an overview of historical cartographical works for landscape development. Furthermore, the changes in the frame of land use in Czechia were solved by Tlapáková et al. (2013) or Štych (2010), who displayed the changes in landscape structure using GIS tools. The assessment of changes in land use development in historical contexts and the subsequent understanding of landscape management is based on Land Use / Land Cover Changes, and on CORINE Land Cover Database (CLC) (Kolejka, 2011). Himiyama (1999) describes the LUCC program that recommends surveying the development of land use structures in the period of the last 300 years. Due to the increasing spatial and temporal resolution of data sources, the recommendation of monitoring land use changes has been reduced to the last 100 years respectively 50 years. Feng and Flewelling (2004) point out that although land use/land cover categories are commonly used in environmental modeling or landscape development, they might be taken as subjective information and thus their interpretation depends on the original purpose of the study and the quality of data sources.

The aim of the widely used CLC database is to display land cover across Europe based on a consistent methodology and regular update of this database. Overall, the database contains 44 categories, with 29 in Czechia and 11 in the study area. Generally, the information on land use through the CLC is taken as supplementary information because of its focus and uniform methodology (Feranec et al., 2000). Land cover categories were also by Rodríguez et al. (1999) for assessing the core of cities of similar size. Ahlqvist (2005) deals more closely with the issue in land cover categories. The study by Feranec et al. (2014) focuses on comparing CORINE Land Cover, National Land Cover Data Set (NLCD) and FAO Land Cover Classification System (LCC). Authors argue that these three typologies together with their similarity (compatibility and interchangeability) are needed to address environmental issues.

The aim of the paper is to document the development of the rural landscape and highlight important causes of land use changes on the example of the Dačice region in Czechia. 


\section{STUDY AREA}

The study area is defined by the administrative boundary of the district of the municipality with extended powers Dačice (hereinafter referred to as MEP). The Dačice rural region lies in the southeast corner of the South Bohemian Region of the Czech Republic (Fig. 1).

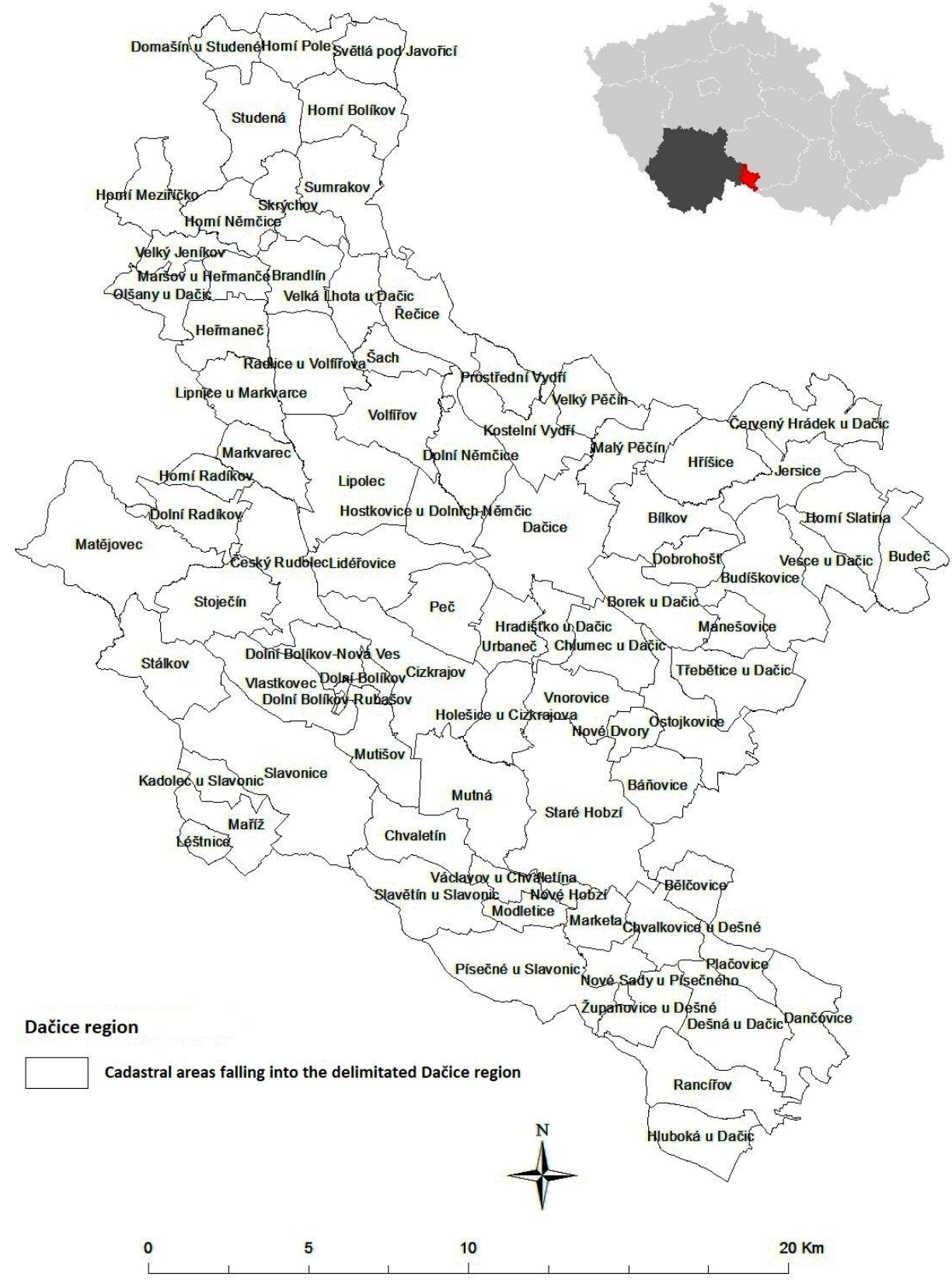

Fig. 1. Cadastral areas within the Dačice region (Source: own processing, geodatabase Arc $\check{C} R$ 500). 
In the north and east it borders the South Moravian Region and the Vysočina Region, the southern border is formed by the state border of the Czech Republic with the federal state Lower Austria, specifically the tourist area Waldviertel.

The border position of the area greatly affects the political, economic and socioeconomic development of the region's landscape. MEP Dačice includes together a total of 23 municipalities situated in 85 cadastral areas with a total area of $472 \mathrm{~km}^{2}$ with a population exceeding 20.000 inhabitants. The population density is 43 inhabitants $/ \mathrm{km}^{2}$, which is a low value compared to other self-governing units in the South Bohemian Region. It reaches only two-thirds of the South Bohemian region's value and less than a third of the Czech Republic's average.

The study area is characterized as an intensively cultivated agricultural area with a smaller proportion of forests. Currently, a total of 27.656 ha of agricultural land is farmed, which represents almost $59 \%$ of the total area of the region. The secondary economic sector occupies the largest number of registered entities in terms of the sector structure of the national economy in the Dačice region. This is followed by the tertiary sector. Although there is the lowest number of registered economical entities in the primary sector, the region has very favorable agricultural conditions in its eastern part.

From the geomorphological point of view, the study area belongs to the extensive subcomposition of the Bohemian-Moravian unit which is a part of the Czech Uplands. The landscape of the Dačice region has a harmonic character that is given especially by its small-sized terrain segmentation created by valleys, small-sized streams and minor forested complexes on the tops of hills with rurally utilized arable lands.

The settlement structure is characterized by the fragmentation of smaller municipalities throughout the study area. Mostly there are municipalities with up to 500 inhabitants (almost 87\%). Most people (64\%) are concentrated in the area of the largest cities - Dačice (39\%) and in the villages Studená and Slavonice (25\%).

\section{DATA AND METHODOLOGY}

The methodology for assessing changes in landscape development in the study area used available data from the Stable Cadastre imperial prints, historical maps and aerial photographs, and the CORINE Land Cover database. GIS software was used to illustrate changes in land cover categories.

The monitored period in 1845, 1948, 2001 and 2014 was determined on the basis of available data, where necessary land use categories (in percentage representation within each cadaster in study area) were provided by records from Czech Office for Surveying, Mapping and Cadastre (years 1845 and 1948) and Cadastral Office in Dačice (years 2001 and 2014). Finally, land use categories were regrouped into seven specific categories according to classification in 2014 - arable land, gardens, permanent grassland, forests, water bodies, built-up areas, and other areas. This reclassification was accepted because the original classification and names of categories in the years 1845 and 1948 were different from those in the years 2001 and 2014. Specifically, reclassification concerned gardens (including orchards and vineyards), permanent grassland (including grassland and pastures), water bodies (including swamps, ponds, lakes, rivers, and streams) and other areas (including infertile land, roads, and tracks). 


\section{RESULTS}

\section{Development of land use categories in the period $1845-2014$}

In the years 1845 - 2014 the area of arable lands decreased by 6\% (Fig. 2). This decline is mainly due to a change in the economic and political situation after World War II, the onset of socialism and the subsequent transformation of the Czech economy during which arable land was gradually grassed. The gradual abandonment of livestock was significantly affected by the loss of permanent grassland by $8 \%$. These areas have been replaced by arable land or have been reforested. The area of forests increased by $8 \%$. Furthermore, the acreage of coniferous forest areas increased in connection with the replacement of mixed forests and afforestation of low stands in their surroundings. A noticeable increase is also observed in the category of other areas by $4 \%$ as a consequence of industrialization and urbanization (construction of new roads, etc.). Although the area of water bodies has increased only by $1 \%$ point, its area (in absolute values) has almost doubled. In the study area, the inhabitants are concentrated mainly in towns or larger municipalities, and therefore there are also elements of suburbanization. As a result, the area was mainly concerned with the afforestation of uncultivated agricultural land, in some places also with slight grassing.

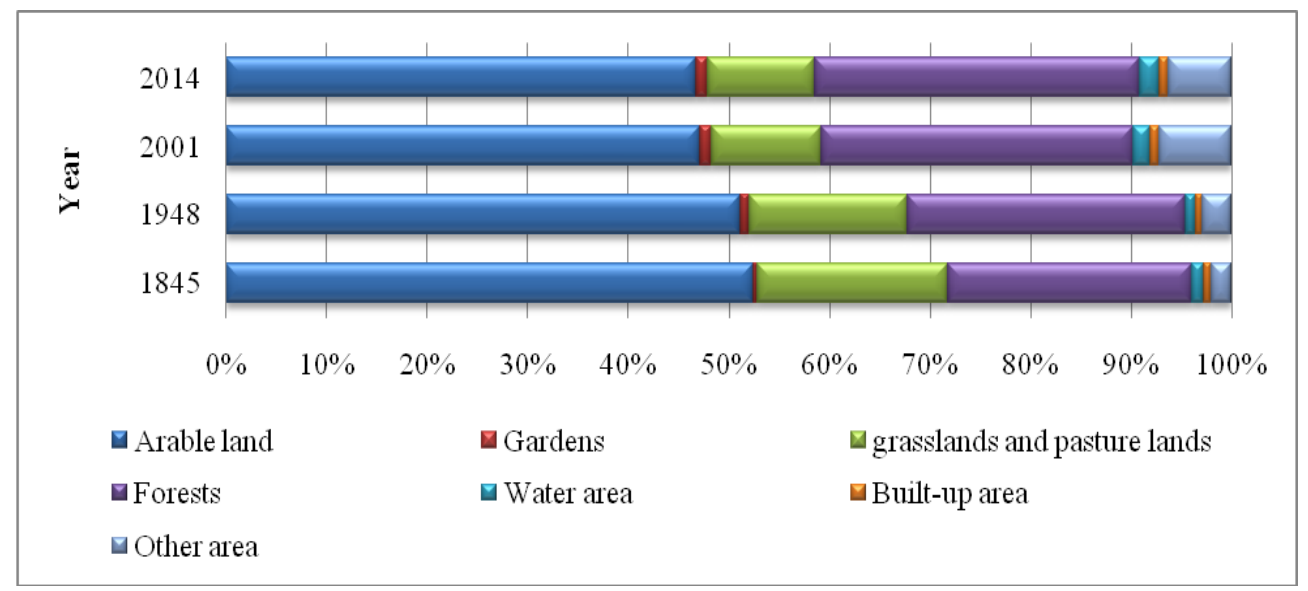

Fig. 2. Proportional representation of individual land use categories between 1845 - 2014 (Source: own processing, data source: Czech Office for Surveying, Mapping, and Cadastre).

\subsection{Arable land}

Arable land reached in Dačice region the highest area (24 602.61 ha) at the beginning of in 1845 (Fig. 3). In the upcoming 100 years, the area of this category decreased minimally. Between 1948 and 2001, arable land decreased to 22411.35 ha. The first decline in this category was due to the economic and political situation that occurred in our country after the end of the Second World War when Czech Germans were transferred from the border region and it remained unsettled. The second decline was caused by the socialization of agriculture and extensive industrialization, through the violent collectivization of the peasants. 


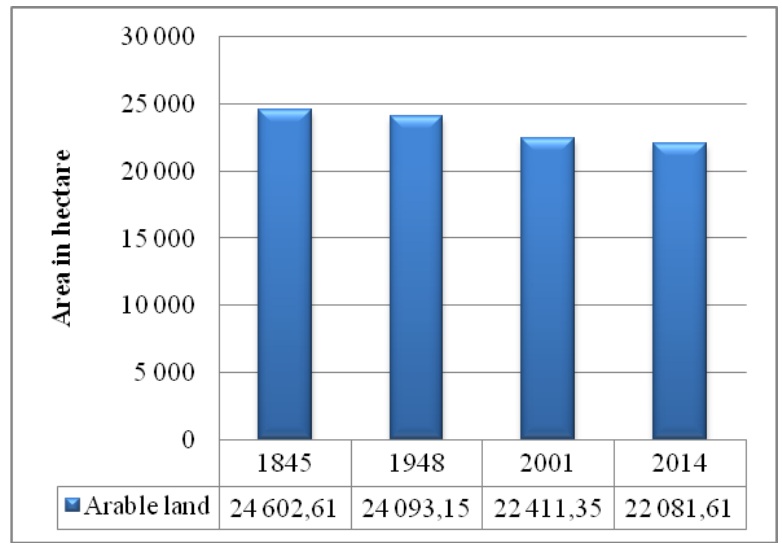

Fig. 3. Changes in arable land area between 1845 and 2014 (Source: own processing, data source: Czech Office for Surveying, Mapping, and Cadastre).

The merging of discontinuous and scattered agricultural areas due to their better accessibility and more efficient use in economic and technical adjustments has led to significant changes in landscape structure. Orthophotos (Fig. 4) illustrate two different situations in 1953 and 2010 which document the area merging process.
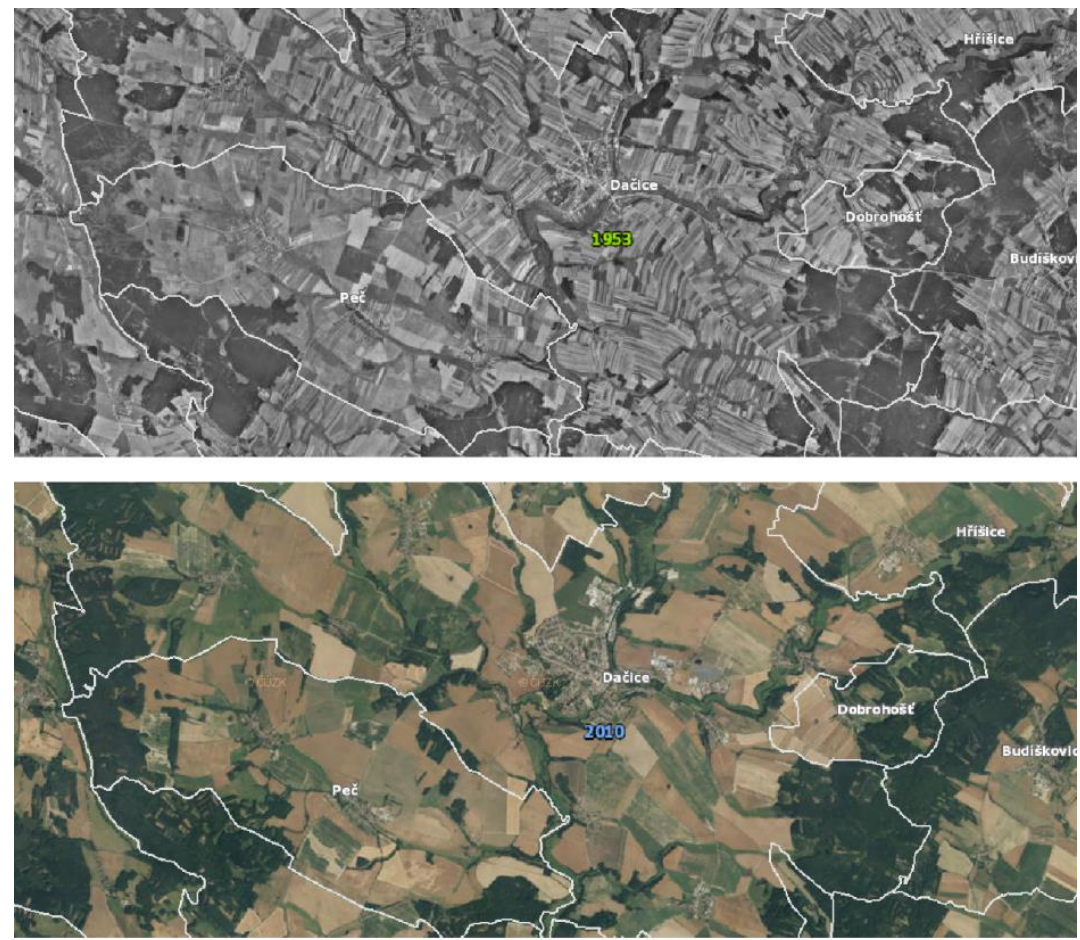

Fig. 4. Landscape structure before and after land consolidation (Source: Czech Office for Surveying, Mapping, and Cadastre). 


\subsection{Gardens}

Gardens represent the largest increase of acreage in the study area. The lowest acreage was reached in 1845 with following gradual growth until today (Fig. 5). Dačice and Slavonice municipalities dominated. Usually, town houses were connected with barns and other farm buildings followed by agricultural areas, which were converted into gardens. Nature protection is very significant in these areas. During the last century, various beautifying associations, alley in the streets and greening the squares were created in the town and the villages, and also fruit gardens were planted near the urban area (built-up areas of municipalities). The aforementioned expansion of tree greenery in streets, especially in villages, was also associated with the change from the economic zone to the rest zone.

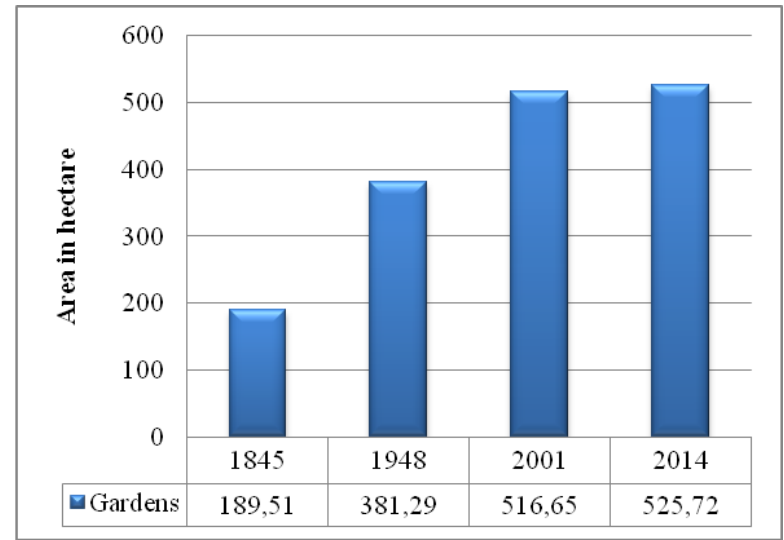

Fig. 5. Changes in gardens area between 1845 and 2014 (Source: own processing, data source: Czech Office for Surveying, Mapping, and Cadastre).

\subsection{Permanent grasslands}

The development of permanent grasslands including meadows and pastures have a typical decreasing character in the long-term period (Fig. 6).

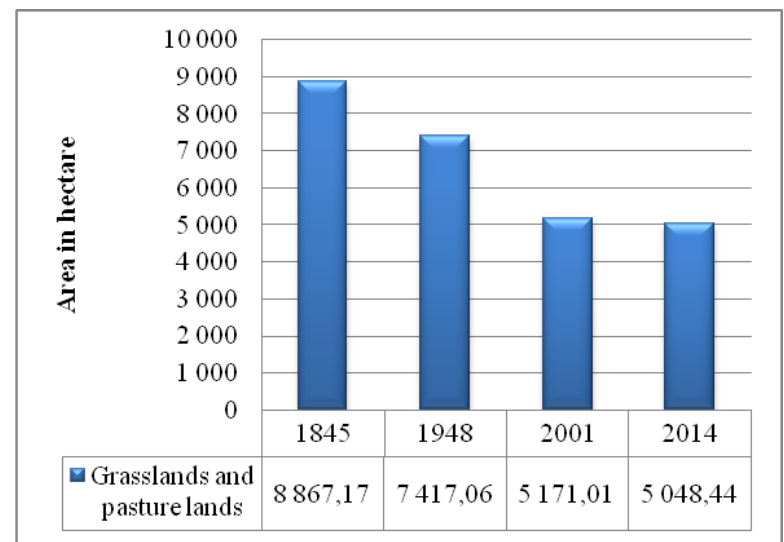

Fig. 6. Changes in permanent grasslands area between 1845 and 2014 (Source: own processing, data source: Czech Office for Surveying, Mapping, and Cadastre). 
The main causes of this decline in 1845-1948 are associated with a decline in livestock farming and the transition from pasture to intensively cultivated agricultural land. In the following years, the decrease in the area of permanent grasslands is connected with the growth of forest influenced by organized planting or spontaneous afforestation.

\subsection{Forests}

Since the beginning of the monitored period, the area of forests has increased (Fig. 7) as a counterpart to the development of agricultural land. In the years 1948 - 2001, the increase of acreage is associated with an afforestation of abandoned, uncultivated agricultural land in higher altitudes and permanent grasslands. Most of forests is located in the western part of the region at the border with Lower Austria, respectively in the villages of Slavonice, Stálkov, Matějovec, and Stoječín, which belong to the natural park Česká Kanada.

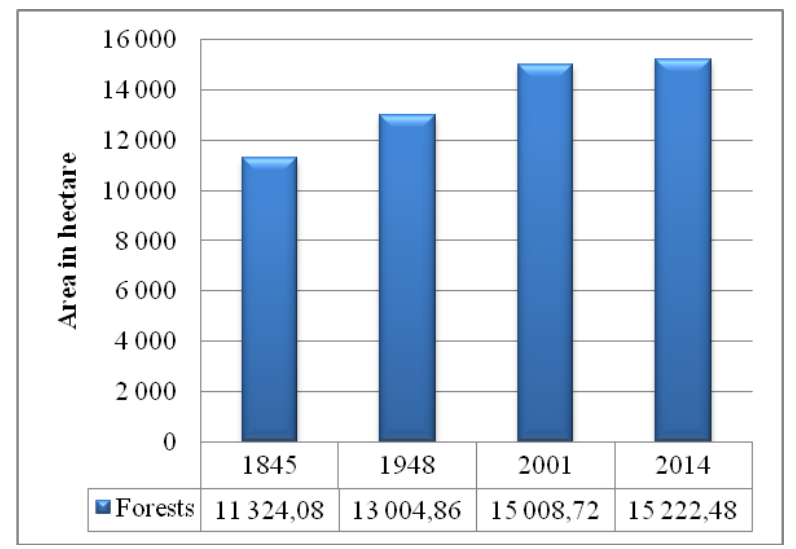

Fig. 7. Changes in forest area between 1845 and 2014 (Source: own processing, data source: Czech Office for Surveying, Mapping, and Cadastre).

At present, a higher proportion of forests can be found in the northern part. Although the village of Staré Hobzí is rather an agriculturally cultivated area, the pro-portion of forests is relatively high, despite the fact that we can see practically the lowest proportion of forests in other areas with the dominanting arable lands and vice versa. Comparing the current orthophotomap with maps from the 3rd Military Mapping Survey illustrates no significant changes in forest areas (Fig. 8). There is a clear increase only in forests in the western part of the Dačice region. Using CLC database terminology, we are talking about the increasing proportion of coniferous trees in already existing mixed forests.

\subsection{Water bodies}

The study area once belonged to one of the largest pond areas in Moravia. The transition from a three-field management system to an alternating (rotary) farming and the cultivation of new fodder crops resulted in a decrease in the area of water bodies in the years 1845 - 1948. In our country, mainly in lowland fertile areas, as well as in highlands and hills, ponds were discharged and sugar beet and potatoes began to grow (Fig. 9). The Dačice region is referred to potato production sub-area B1, including the cultivation of ware, industrial and seed potatoes, feed grains, rape, and flax. The largest proportion of water bodies is located in the northwestern and western parts of the region (Studená, Horní Meziřričko, Volfǐřov, Lipnice, Markvarec, etc.). A relatively large part of larger water 
bodies is situated in the center of the Dačice region, on the western edge (there is a cascade of ponds) and around the town of Slavonice and in the village of Český Rudolec. Czech fish farming has a long tradition and together with the European Union funds not only large fishing companies but also private family fishing companies are supported.
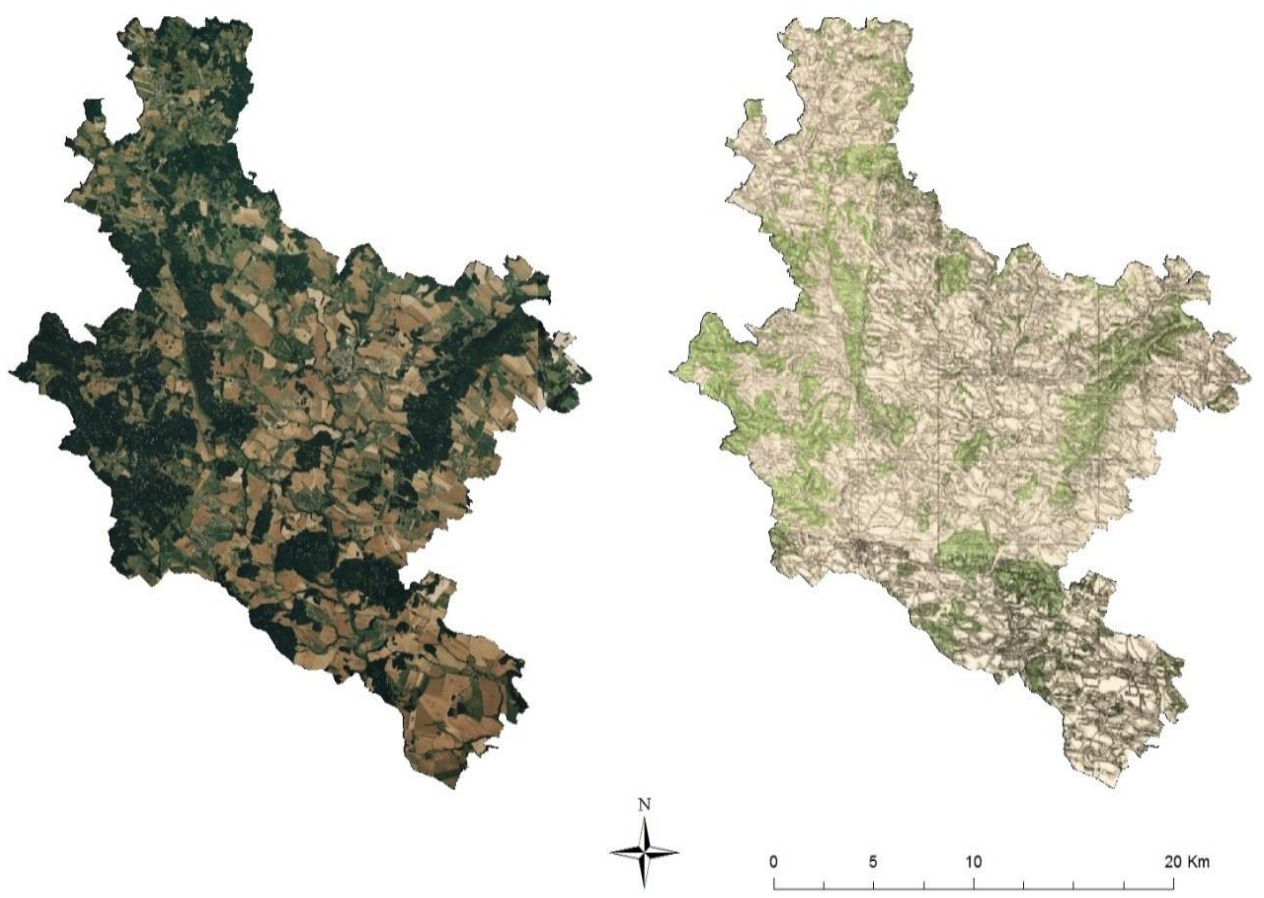

Fig. 8. Comparing the area of forests between orthophoto (dark green color) in 2014 (left) and map (green color) from the 3rd Military Mapping Survey (right) (Source: Czech Office for Surveying, Mapping, and Cadastre).

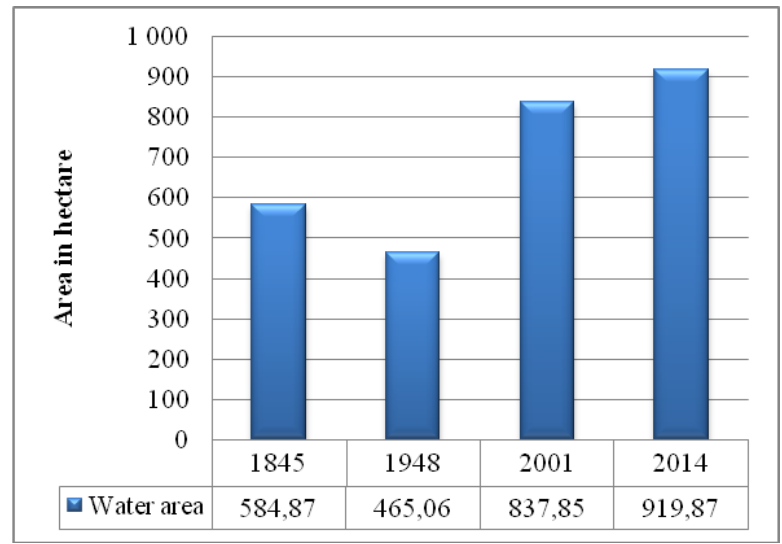

Fig. 9. Changes in water bodies area between 1845 and 2014 (Source: own processing, data source: Czech Office for Surveying, Mapping, and Cadastre). 


\subsection{Built-up areas}

Between 1845 and 1948, the size of the built-up areas was reduced (Fig. 10). This phenomenon is linked to both World Wars and the transfer of the German population from the border. On the basis of the Munich Dictation, the Dačice region had to withdraw its borderland, namely 26 municipalities, in favor of Nazi Germany.

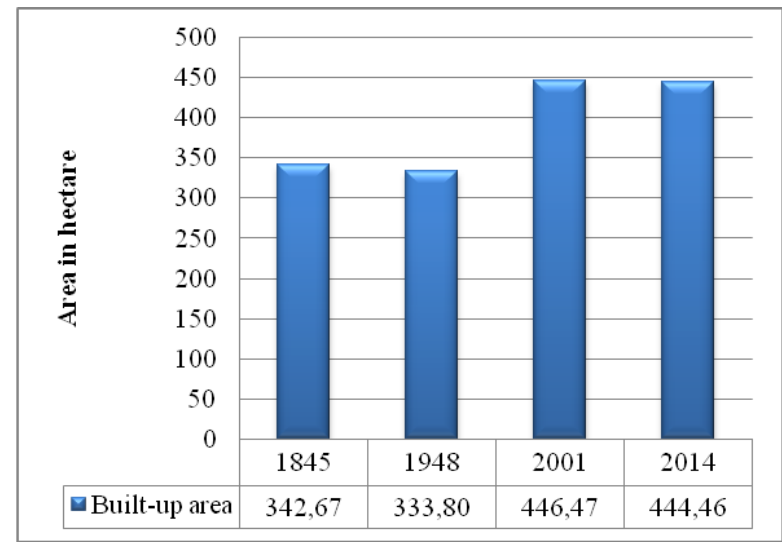

Fig. 10. Changes in built-up area between 1845 and 2014 (Source: own processing, data source:

Czech Office for Surveying, Mapping, and Cadastre).

This territorial change lasted until 1945. Between 1948 and 2001, the increase of builtup areas was influenced by the concentration of the population in cities and rural settlements. Especially with the rise of socialism and the importance of industrialization, the character of populated areas, such as housing development, expansion of industrial zones outside the city and suburbanization, has changed (Fig. 11). In the villages, family houses and cottages including agricultural buildings were built.

The original character of these villages is distorted by the current construction of family houses. In smaller cadastral areas, the original character of the settlement is still preserved. Between the years 2000 - 2006, changes recorded in the CLC database concerned the builtup areas and the separated residential development areas in Dačice. Within these years, family and residential buildings were built on the western edge of the city. In addition, two separate residential development areas have been added, but they are not recorded as changes in the CLC database. The original character of these villages is distorted by the current construction of family houses. In smaller cadastral areas, the original character of the settlement is still preserved. Within these years, family and residential buildings were built on the western edge of the city.

\subsection{Other areas}

Concerning this category we observe a significant change after 1948 when there was intensive construction of paved roads, production and storage areas, construction of industrial and municipal waste dumps, etc. (Fig. 12). Other areas include not only manmade landscape elements (roads, handling areas, quarries, landfills, etc.) but also unused or infertile land (protected areas, nature parks). The increase of the area of this category was also strongly influenced by the process of industrialization and urbanization, but moreover, there is a significant influence of nature and landscape protection. A significant part of the area of other areas is located in the northern part of the region around the villages of Studená, Horní Bolík, Sumrakov, Horní Pole and Světlá pod Javořicí. 


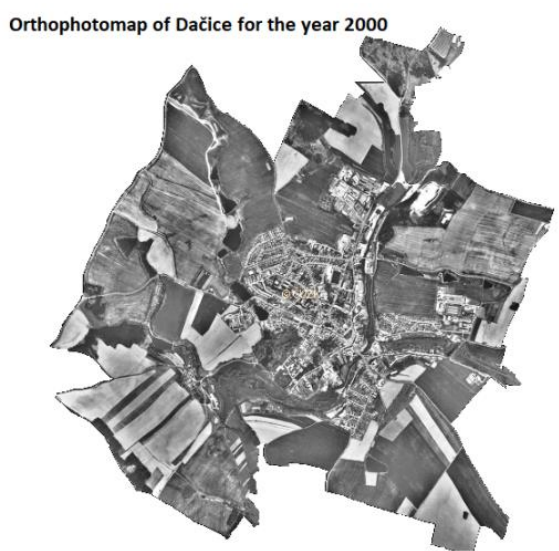

Orthophotomap of Dačice for the year 2007

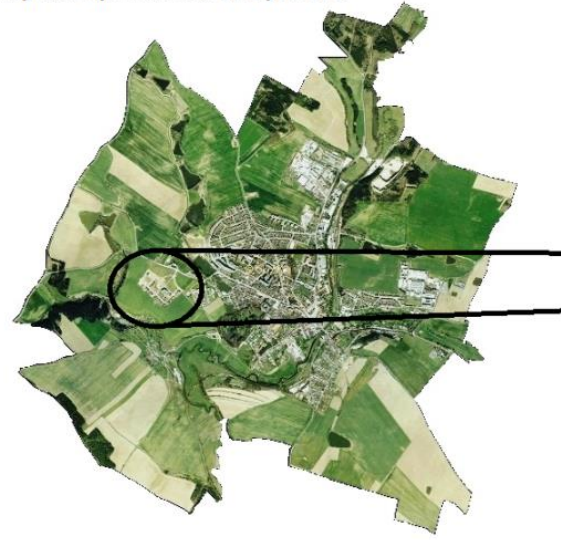

CLC of Dačice for the year 2000

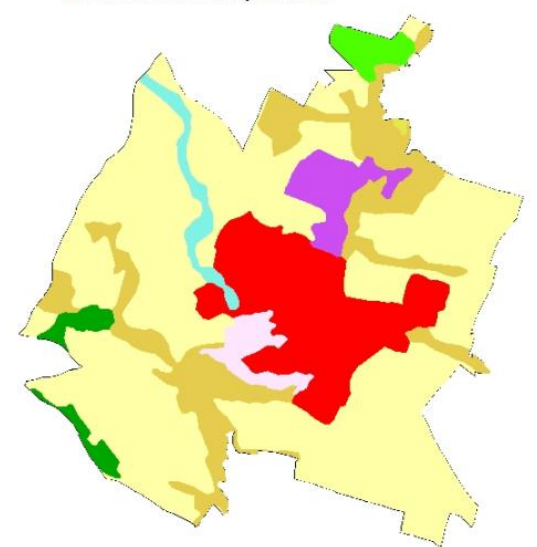

CLC change between years 2000 and 2006

Fig. 11. Increase of built-up areas in the Dačice region during the suburbanization between 2000 2006 (Source: own processing according to CLC and geoportal.gov).

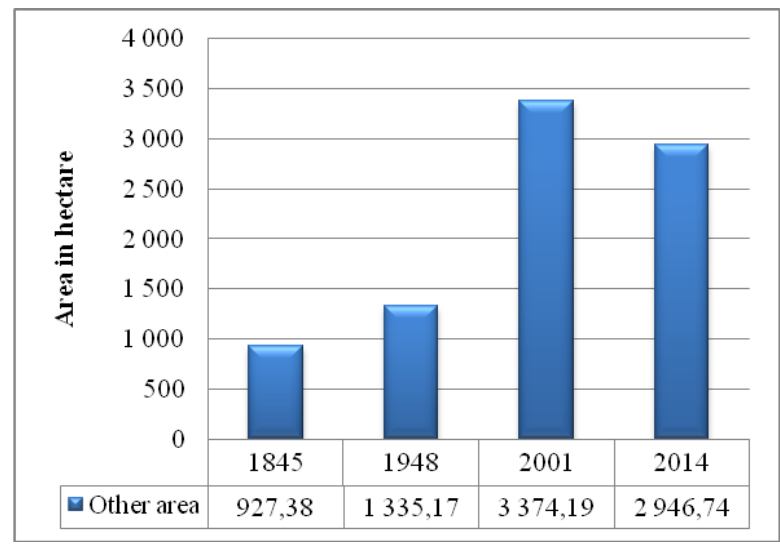

Fig. 12. Changes in other areas between 1845 and 2014 (Source: own processing, data source: Czech Office for Surveying, Mapping, and Cadastre). 


\section{CONCLUSION}

The Dačice Region is appreciated especially for its distinctive character of the landscape and preserved architectural and cultural wealth. Generally, it is a rural area with a high proportion of agricultural land. The onset of socialism was the period of the strongest impacts on the landscape. The landscape character was heavily affected due to the technical and economic changes in land consolidation. The transition from the centrally planned economy to the market economy, a period of transformation and restructuralisation in the 1990s, had a significant impact on the countryside and its land cover. In spite of larger or smaller interventions, the territory is characterized by a historically preserved urban structure of settlements. Here, it is appropriate to further protect the territory development as well.

\section{Acknowledgements}

The paper Development of the rural landscape: Dačice region case study, Czechia is the result of a study that was conducted within the project of Internal Grant Agency of Faculty of Regional Development and International Studies No 16/2015 - The chosen environmental tools as the regional development factors.

\section{R E F E R E N C E S}

Ahlqvist, O. (2005) Using uncertain conceptual space to translate between land cover categories. International Journal of Geographical Information Science, 19 (7), 831-857.

Bičík, I., Jeleček, L. \& Štěpánek, V. (2001) Land use changes and their social driving forces in Czechia in the 19th and 20th centuries. Land Use Policy, 18 (3), 65-73.

Bičík, I. (2012) Vývoj využití ploch v Česku. Česká geografická společnost, Praha.

Bičík, I. \& Kupková, L. (2006) Vývoj využití ploch v Pražském městském regionu. In: Ouředníček, M. (ed.) Sociální geografie Pražského městského regionu. Univerzita Karlova v Praze, Praha. pp. 41-61.

Brůna, V. \& Křováková, K. (2005a) Staré mapy jako cenný zdroj informací o stavu a vývoji krajiny: Mostecko na starých mapách. Zahrada-Park-Krajina, 4, 25-29.

Brůna, V., Křováková, K. (2005b) Analýza změn krajinné struktury s využitím map stabilního katastru. Historické mapy. Zborník referátov z vedeckej konferencie Bratislava: Kartografická spoločnost' Slovenskej republiky. pp. 1-8.

Bürgi, M., Hersperger, A. M. \& Schneeberger, N. (2004) Driving forces of landscape change current and new directions. Landscape Ecology, 19 (8), 857-868.

Bürgi, M. \& Russell, E. (2001) Integrative methods to study landscape changes. Land use policy, 18 (1), 9-16.

Melillo, Jerry M., Terese (T. C.) Richmond \& Gary W. Yohe (2014) Climate Change Impacts in the United States. The Third National Climate Assessment. U.S. Global Change Research Program, Washington.

Eremiášová, R. \& Skokanová, H. (2009) Land use changes (recorded in old maps) and delimitation of the most stable areas from the perspective of land use in the Kašperské hory region. Journal of Landscape Ecology, 2 (1), 20-34.

Feranec, J., Bossard, M. \& Otahel, J. (2000) CORINE land cover technical guide - Addendum 2000. European Environment Agency, Copenhagen.

Feranec, J., Solin, L., Kopecká, M., Otahel, J., Kupková, L., Štych, P., Bičík, I., Kolar, J., Čerba, O., Soukup, T. \& Brodský, L. (2014) Analysis and expert assessment of the semantic similarity between land cover classes. Progress in Physical Geography, 38 (3), 301-327. 
Feng, C. C. \& Flewelling, M. D. (2004) Assessment of semantic similarity between land use/land cover classification systems. Computers, Environment and Urban Systems, 28 (3), 229-246.

Himiyama, Y. (1999) Historical information bases for land use planning in Japan. Land Use Policy, 16 (3), $145-151$.

Irwin, E. G. \& Geoghegan, J. (2001) Theory, data, methods: developing spatially explicit economic models of land use change. Agriculture, Ecosystems and Environment, 85 (1-3), 7-24.

Kolejka, J. (2011) Krajina Česka a Slovenska v současném výzkumu. Masarykova univerzita, Brno.

Lipský, Z. (2011) Protichůdné tendence současného vývoje české venkovské krajiny a jejich důsledky: opuštěná půda a vznik nové divočiny v kulturní krajině. In: Kolejka, J. (ed.) Krajina Česka a Slovenska $v$ současném výzkumu. Masarykova univerzita, Brno. pp. 196-222.

Lipský, Z. (1994) Změna struktury české venkovské krajiny. Sborník České geografické společnosti, 99 (4), 248-260.

Loveland, T. \& Mahmood, R. (2014) A Design for a Sustained Assessment of Climate Forcing and Feedbacks Related to Land Use and Land Cover Change. Bulletin of the American Meteorological Society, 95 (10), 1563-1572.

Nistor, M-M., Man, T. C., Benzaghate, M. A., Nedumpallile Vasu, N., Dezsi, S., Kizza, R. (2018) Land Cover temperature implications fro the seasonal evapotranspiration in Europe. Geographia Technica, 13 (1), 85-108.

Olah, B., Boltižiar, M., Petrovič, F. \& Gallay, I. (2006) Vývoj využitia krajiny slovenských biosférických rezervácií UNESCO. Technická univerzita Zvolen, Zvolen.

Plánka, L. (2013) Historická kartografická díla České republiky pro studium vývoje krajiny. Životní prostředí, 47 (1), 3-7.

Rodrígues, A. M., Egenhofer J. M. \& Rug, D. R. (1999) Assessing semantic similarities among geospatial feature class definitions. In: Vckovski, K. E., Brassel, E. K. and Schek, J-H. (eds.) INTEROP'99, Berlin, Springer. pp. 189-202.

Rounsevell, Mark D. A., Pedroli, B., Erb, K. H., Gramberger, M., Gravsholt Busck, A., Haberl, H., Kristensen, S., Kuemmerle, T., Lavorel, S., Lindner, M., Lotze-Campen, H., Metzge, M. J., Murray-Rust, D., Popp, A., Pérez-Soba, M., Reenberg, A., Vadineanu, A., Verburg, P. H. \& Wolfslehner, B. (2012) Challenges for land system science. Land Use Policy, 29 (4), 899-910.

Skaloš, J., Weber, M., Lipský, Z., Trpáková, I., Šantrůčková, M., Uhlírová, L. \& Kukla, P. (2011) Using old military survey maps and orthophotograph maps to analyze long-term land cover changes - Case study (Czech Republic). Applied Geography, 31 (2), 426-438.

Št’astná, M., Vaishar, A., Vavrouchová, H., Ševelová, M., Kozlovská, S., Doskočilová, V. \& Lincová, H. (2015). Changes Of A Rural Landscape In Czech Areas Of Different Types. European Countryside, 7 (2), 111-133.

Štych, P. (2010). Evaluation of long-term land-use changes in case studies in Central Bohemia. Bohemi centralit. Praha, 30, 121-137.

Tlapáková, L., Stejskalová, D., Karásek, P. \& Podhrázská, J. (2013) Landscape Metrics as a Tool for Evaluation Landscape Structure - Case Study Hustopeče. European Countryside, 5 (1), 52-70. 